\title{
Prestasi Belajar Mahasiswa Angkatan 2018 antara Semester Genap Tahun 2018/2019 dan 2019/2020
}

\author{
Heri Irawan, Siti Nurrochmah* \\ Universitas Negeri Malang, Jl. Semarang No. 5 Malang, Jawa Timur, Indonesia \\ *Penulis korespondensi, Surel: siti.nurrochmah.fik@um.ac.id
}

Paper received: 24-5-2021; revised: 14-6-2021; accepted: 21-6-2021

\begin{abstract}
The purpose of the study is to find out and review whether there are differences in even semester learning achievement between 2018/2019 and 2019/2020 in students of the class of 2018 PJKR-FIKUM study program. The design in this study uses a causal comparative design. The population in this study was students of PJKR-FIK-UM Study Program which amounted to 39 people. The samples were taken using purposive random sampling technique of 90 percent so that the samples studied amounted to 35 people. Data analysis techniques using T test $\alpha 0.05$, there is no significant difference between the study results of students of the class of 2018 even semester in 2018/2019 and 2019/2020 PJKR-FIK-UM study program.
\end{abstract}

Keywords: Learning Achievement; Even Semester 2018/2019 and 2019/2020

\begin{abstract}
Abstrak
Tujuan penelitian untuk mengetahui dan mengkaji apakah ada perbedaan prestasi belajar semester genap antara tahun 2018/2019 dan 2019/2020 pada mahasiswa angkatan 2018 Prodi PJKR-FIK-UM. Rancangan dalam penelitian ini menggunakan rancangan causal comparative. Populasi dalam penelitian ini adalah mahasiswa Prodi PJKR-FIK-UM yang berjumlah 39 orang. Sampel yang diambil menggunakan teknik purposive random sampling 90 persen, sehingga sampel berjumlah 35 orang. Teknik analisis data menggunakan uji T $\alpha 0,05$, tidak terdapat perbedaan yang signifikan antara hasil belajar mahasiswa angkatan 2018 Semester genap tahun 2018/2019 dan 2019/2020 Prodi PJKRFIK-UM.
\end{abstract}

Kata kunci: Prestasi Belajar; Semester Genap 2018/2019 dan 2019/2020

\section{Pendahuluan}

Prestasi belajar adalah salah satu indikator keberhasilan seseorang dalam menempuh kegiatan pembelajaran di lingkungan pendidikan. semua orang yang melakukan kegiatan pembelajaran pastinya ingin mendapatkan prestasi belajar yang baik. prestasi belajar yang baik pastinya didapatkan dengan proses pembelajaran yang baik pula. Meskipun demikian tidak semua orang yang melakukan proses pembelajaran mendapatkan prestasi yang baik, salah-satunnya prestasi belajar yang diraih oleh peserta didik yang ada dilingkungan pendidikan. Soepardjo (2013), mengatakan hasil belajar yang didapatkan menunjuk pada prestasi belajar sedangkan prestasi belajar menunjuk pada tingkat perubahan perilaku peserta didik. Thobroni (2015), "hasil belajar merupakan perubahan perilaku pada individu secara keseluruhan setelah proses belajar". Capaian prestasi belajar yang diperoleh siswa sangat diharapkan capaian hasil yang optimal. Hal tersebut juga terjadi di lingkungan pendidikan perguruan tinggi seperti pada mahasiswa Prodi PJKR. Mahasiswa dalam mengikuti proses pembelajaran berupaya semaksimal mungkin agar akhir dari pembelajaran salah satu harapan adalah memperoleh prestasi yang optimal. 
Pembelajaran atau perkuliahan di Prodi PJKR, mahasiswa dituntut belajar pada dua domain secara bersamaan, yaitu belajar mata kuliah praktik atau belajar gerak dan belajar mata kuliah teori yaitu berhubungan dengan domain kognitif. Di samping pelaksanan dilakukan mendekati bersamaan misalnya jam 1-2 belajar gerak jam 3-4 belajar mata kuliah teori atau sebaliknya. Hal tersebut berlaku pula ketika pelaksanaan ujian akhir semester atau proses evaluasi hasil belajar. Melihat kondisi tersebut di Prodi PJKR, langka mahasiswa memperoleh IP 4.0. Prestasi belajar di perguruan tinggi ditunjukkan ke dalam bentuk indek prestasi. Dimana jumlah nilai dikalikan bobot sks dibagi dengan jumlah SKS dari matakuliah yang diambil setiap semester.

Dalam satuan pendidikan di perguruan tinggi hasil belajar selama masa perkuliahan dituliskan dalam bentuk kartu hasil studi. Kartu hasil studi bisa dijadikan sebagai acuan mahasiswa untuk melihat tingkat prestasi belajarnya. Keberhasilan mahasiswa dalam mencapai prestasi belajar merupakan salah satu indikator keberhasilan dalam mencapai kesuksesan dimasa depannya. Prestasi yang dimaksudkan pada penelitian ini adalah prestasi yang didapatkan oleh mahasiswa selama melakukan proses pembelajaran di lingkungan satuan pendidikan di perguruan tinggi yang dinyatakan dalam bentuk angka disebut dengan IPK atau indeks prestasi Kumulatif. Pada mahasiswa angkatan 2018 Prodi PJKR-FIK-UM.

Proses pembelajaran pada saat ini mengalami perubahan dimana mahasiswa angkatan tahun 2018 di awal semester genap tahun 2018/2019 mahasiswa melakukan proses pembelajaran seperti biasa dengan menggunakan metode pembelajaran luring. pembelajaran luring merupakan sistem pembelajaran tatap muka. Sunendar (2020), dalam KBBI disebutkan bahwa istilah luring merupakan akronim luar jaringan. Misalnya belajar melalui buku atau belajar langsung dengan tatap muka. Sedangkan pada awal semester genap tahun 2019/2020 mahasiswa melakukan proses pembelajaran dengan menggunakan dua metode pembelajaran yaitu luring dan daring. Hal ini dikarenakan dunia sedang dikejutkan dengan adanya sebuah virus yang memiliki dampak besar bagi aspek kehidupan virus ini dinamakan dengan istilah covid 19 (WHO, 2020). Berdasarkan surat edaran Kemendikbud Dikti No. 1 tahun 2020. Kementerian pendidikan dan kebudayaan telah melarang semua jenjang pendidikan mulai dari TK, SD, SMP, SMA bahkan perguruan tinggi untuk melaksanakan pembelajaran secara tatap muka (konvensional). Hal ini membuat proses pembelajaran dilakukan secara daring.

Sofyana \& Abdul (2019), pembelajaran daring adalah proses belajar yang dilakukan tanpa harus bertatap muka langsung, tapi belajar dengan jarak jauh dengan bantuan internet dengan menggunakan platform seperti google meet. Selain itu belajar dengan menggunakan sistem daring dapat memberikan pelayanan belajar yang bermutu dalam jaringan yang sifatnya lebih luas dan terbuka.

Melihat pada proses pembelajaran daring di seluruh jenjang pendidikan saat ini belum sepenuhnya efektif dan berjalan dengan baik, hal ini didasari pengalaman pribadi dari peneliti yang pernah mengalami proses pembelajaran secara daring. Dimana dalam proses pembelajaran daring memiliki berbagai kendala seperti halnya dalam perangkat pembelajaran, terbatasnya koneksi jaringan internet di daerah tempat tinggal peserta didik seringkali peserta didik telat bahkan tidak mengikuti kegiatan belajar mengajar dengan alasan tersebut. Proses pembelajaran daring juga belum bisa dikatakan efektif pada beberapa mata pelajaran atau mata kuliah khususnya pembelajaran yang hubungannya dengan aktivitas gerak salah satunya pembelajaran pendidikan jasmani. Menurut pengalaman pribadi peneliti dalam 
pembelajaran pendidikan jasmani yang kaitannya dengan aktivitas gerak akan lebih efektif apabila dilaksanakan secara tatap muka atau berinteraksi langsung dengan pendidik. Kurangnya tingkat keefektifitasan pada pembelajaran daring akan dapat mempengaruhi hasil prestasi belajar peserta didik khususnya pada pelajaran atau mata kuliah pendidikan jasmani yang disajikan pada setiap semesternya.

Terkait dengan prestasi belajar, penelitian terdahulu oleh Husnawati \& Rafiul Aila1 (2018), tentang masalah "Perbedaan Prestasi Belajar Mahasiswa Lulusan Madrasah Aliyah dan Sekolah Menengah Umum Pada Mata Pelajaran Bahasa Arab" di perguruan tinggi STAI Tapaktuan Aceh Selatan, sedangkan rencana masalah yang diteliti oleh peneliti adalah Perbedaan Prestasi Belajar Mahasiswa Angkatan 2018 Antara Semester Genap Tahun 2018/2019 dan 2019/2020 Prodi PJKR-FIK-UM. Dari jenis penelitian terdahulu tersebut dan masalah yang akan peneliti teliti adalah prestasi belajar pada mahasiswa prodi PJKR FIK UM, berarti masalah yang akan peneliti dikaji berbeda secara substansi termasuk lembaga yang dilibatkan."

Oleh karena Perbedaan Prestasi Belajar Mahasiswa Angkatan 2018 Antara Semester Genap Tahun 2018/2019 dan 2019/2020 Prodi PJKR-FIK-UM belum pernah ada peneliti lain yang meneliti, maka peneliti tertarik mengkaji tentang masalah prestasi belajar mahasiswa prodi PJKR angkatan 2018 melalui penelitian. Berdasarkan permasalahan yang telah dipaparkan tersebut dan didukung dengan penelitian terdahulu. Peneliti tertarik untuk melakukan pengkajian tentang hasil belajar berupa prestasi belajar mahasiswa angkatan 2018 melalui penelitian berjudul, "Perbedaan Prestasi Belajar Mahasiswa Angkatan 2018 Antara Semester Genap Tahun 2018/2019 dan 2019/2020 Prodi PJKR-FIK-UM".

\section{Metode}

Penelitian ini menggunakan rancangan survey dan metode yang digunakan berupa metode dokumentasi. penelitian ini termasuk jenis penelitian ex post facto bentuk causal comparative. Variabel yang diteliti meliputi variabel terikat berupa nilai prestasi belajar dan variabel bebas meliputi nilai prestasi belajar semester genap 2018/2019 dan semester genap 2019/2020. Pengambilan data dilakukan dengan menggunakan metode dokumentasi bentuk nilai hasil belajar yang tercantum pada KHS mahasiswa angkatan 2018 Prodi PJKR-FIK-UM semester genap tahun 2018/2019 dan 2019/2020. Setelah data terkumpul kemudian data dianalisis menggunakan uji t sampel berhubungan yang sebelumnya dilakukan uji normalitas menggunakan teknik kolmogorov-smirnov dan homogenitas varian dalam kelompok.

Populasi mahasiswa angkatan 2018 prodi PJKR-FIK-UM. Offering A berjumlah 39 orang yang melaksanakan pembelajaran di semester genap tahun 2018/2019 dan semester genap tahun 2019/2020. Pengambilan sampel menggunakan teknik purposive proportional systematic random sampling dengan porsi 90\%. Sehingga sampel berjumlah 35 orang.

Penelitian ini menggunakan instrumen non tes bentuk dokumentasi data terkait hasil belajar yang tercantum pada KHS semester genap tahun 2018/2019 dan semester genap tahun 2019/2020 pada mahasiswa angkatan tahun 2018 prodi PJKR-FIK-UM. 


\section{Hasil dan Pembahasan}

\subsection{Hasil}

\subsubsection{Hasil Uji Normalitas}

Uji normalitas dilakukan untuk menguji data dari semua variabel yang diteliti berdistribusi normal atau tidak. Teknik uji normalitas pada penelitian ini menggunakan teknik kolmogorov-smirnov untuk menguji hasil prestasi belajar mahasiswa prodi PJKR-FIK-UM pada hasil prestasi belajar semester genap tahun 2018/2019 dan semester genap 2019/2020. Data dianalisis menggunakan statistika deskriptif, pengujian hipotesis menggunakan $\alpha 0,05$.

Berdasarkan hasil analisis data normalitas pada variabel prestasi belajar semester genap tahun 2018/2019 dan semester genap tahun 2019/2020 diperoleh hasil Dhit 0,112< Dtab 0,224 dan Dhit 0,134< Dtab 0,224 dengan pengujian hipotesis menggunakan $\alpha 0,05$. Berarti hasil prestasi belajar pada variabel prestasi belajar semester genap tahun 2018/2019 dan semester genap tahun 2019/2020 berdistribusi normal. Sehubungan dengan hasil analisis data yang berdistribusi sehingga dapat dilanjutkan ke uji homogenitas

\subsubsection{Hasil Uji Homogenitas}

Uji normalitas dilakukan untuk menguji hasil prestasi belajar mahasiswa prodi PJKRFIK-UM pada hasil prestasi belajar semester genap tahun 2018/2019 dan semester genap 2019/2020 menggunakan teknik uji F varian kelompok dengan pengujian pengujian hipotesis menggunakan $\alpha 0,05$

Hasil analisis data uji homogenitas pada variabel prestasi belajar semester genap tahun 2018/2019 dan semester genap tahun 2019/2020 diperoleh hasil Fhit 0,317 < Ftab 1,772 dengan pengujian hipotesis menggunakan taraf signifikan $\alpha 0,05$. Berdasarkan paparan tersebut dapat disimpulkan bahwa hasil varian dalam kelompok berasal dari varian yang homogen

\subsubsection{Hasil Analisis Uji t Sampel Tidak Bebas}

Hasil analisis uji beda sampel tidak bebas diperoleh thit $-1,032245$ dan ttab 2,032245 $\alpha$ 0,05 terhadap variabel prestasi belajar semester genap tahun 2018/2019 dan semester genap tahun 2019/2020.

Tabel 1. Hasil Uji Beda (T) Sampel Tidak Bebas Bebas terhadap Variabel Prestasi Belajar Semester Genap Tahun 2018/2019 dan Semester Genap Tahun 2019/2020

\begin{tabular}{|c|c|c|c|c|c|c|}
\hline No & Variabel & Semester & $\begin{array}{l}\text { Rata- } \\
\text { rata }\end{array}$ & $\begin{array}{l}\text { Hasil } \\
\text { Uji thit. }\end{array}$ & $\begin{array}{l}t_{\text {tab. }} \text { db. } N- \\
1 \\
(\alpha=0,05)\end{array}$ & $\begin{array}{l}\text { Keterangan } \\
(\alpha 0,05)\end{array}$ \\
\hline 1 & \multirow[b]{2}{*}{$\begin{array}{l}\text { Prestasi } \\
\text { belajar }\end{array}$} & $\begin{array}{l}\text { Genap } \\
(2018 / 2019)\end{array}$ & 3,37 & \multirow[b]{2}{*}{$-1,0146$} & \multirow[b]{2}{*}{2,032245} & \multirow{2}{*}{$\begin{array}{l}\text { thit. }<\text { ttab. } \alpha 0,05 \\
\text { Tidak terdapat } \\
\text { perbedaan } \\
\text { prestasi belajar } \\
\text { semester genap } \\
\text { tahun }\end{array}$} \\
\hline 2 & & $\begin{array}{l}\text { Genap } \\
(2019 / 2020)\end{array}$ & 3,40 & & & \\
\hline
\end{tabular}


Sport Science and Health, 3(6), 2021, 350-358

\begin{tabular}{|c|c|c|c|c|c|c|}
\hline No & Variabel & Semester & $\begin{array}{l}\text { Rata- } \\
\text { rata }\end{array}$ & $\begin{array}{l}\text { Hasil } \\
\text { Uji thit. }\end{array}$ & $\begin{array}{l}\text { ttab. db. N- } \\
1 \\
(\alpha=0,05)\end{array}$ & $\begin{array}{l}\text { Keterangan } \\
(\alpha 0,05)\end{array}$ \\
\hline & & & & & & $\begin{array}{l}2018 / 2019 \text { dan } \\
2019 / 2020\end{array}$ \\
\hline
\end{tabular}

Hasil analisis data uji beda (T) sampel tidak bebas pada Variabel prestasi semester genap tahun 2018/2019 dan semester genap tahun 2019/2020 dengan jumlah sampel 35 mahasiswa diperoleh hasil Thit $<$ Ttab $-1,0146<2,032245$ taraf signifikan $\alpha 0,05$. Artinya dapat disimpulkan tidak terdapat perbedaan prestasi belajar mahasiswa angkatan 2018 antara semester genap tahun 2018/2019 dan 2019/2020 Prodi PJKR-FIK-UM.

\subsection{Pembahasan}

Berdasarkan hasil paparan data yang telah diuji di tabel 1 hasil prestasi belajar mahasiswa angkatan 2018 semester genap tahun 2018/2019 dan 2019/2020 dengan jumlah sampel 35 mahasiswa diperoleh hasil koefisien thit < ttab. Berarti dapat dikemukakan bahwa tidak ada perbedaan yang signifikan antara prestasi belajar semester Genap Tahun.2018/2019 dan semester Genap Tahun 2019/2020. Adapun hasil rata-rata hitung pada variabel prestasi belajar semester genap tahun 2018/2019 diperoleh nilai rata-rata 3,37 dan pada variabel prestasi belajar semester genap tahun 2019/2020 diperoleh nilai rata-rata 3,40. Sehingga dapat diketahui bahwasannya hasil prestasi belajar semester Genap Tahun 2019/2020 cenderung lebih baik daripada hasil prestasi belajar semester Genap Tahun 2018/2019

Tidak adanya perbedaan yang signifikan pada hasil Prestasi belajar tersebut dipengaruhi oleh beberapa faktor yaitu faktor internal yang berasal dari dalam diri individu dan eksternal yang berasal dari luar (Slameto, 2015). Salah satu faktor yang mempengaruhi hasil prestasi tersebut ialah proses pembelajaran. Febianti \& Joharudin (2018), berpendapat bahwa prestasi belajar dipengaruhi oleh proses pembelajaran, metode yang digunakan saat pembelajaran, sumber, evaluasi, mahasiswa, lingkungan, serta kesehatan dan bakat yang dimiliki. Mudjiono (2015), Proses pembelajaran adalah suatu kegiatan interaksi peserta didik dan pendidik dimana akan terjadi kegiatan evaluasi atau penilaian pada hasil belajar peserta didik.

Wiarto (2015), menyatakan bahwa keberhasilan seseorang dalam belajar dapat dipengaruhi oleh faktor bawaan,tempat tinggal, kematangan, usaha dari individu secara aktif sedangkan menurut Rahyubi (2014), berpendapat faktor yang mempengaruhi pembelajaran motorik adalah faktor diri sendiri, lingkungan, peralatan, serta kehadiran pengajar yang menjadi fasilitator. Empat hal ini saling berkaitan agar pembelajaran motorik berjalan secara optimal. Jika hal ini tidak terpenuhi kemungkinan besar pembelajaran motorik kurang optimal sehingga hasil yang didapatkan tidak memuaskan.

Proses pembelajaran pada jenjang perguruan tinggi berbeda, perbedaan ini disesuaikan dengan tingkat semester dan jenis mata kuliah yang akan ditempuh pada semester tersebut. Dalam penelitian ini mahasiswa menempuh proses pembelajaran pada semester Genap Tahun 2018/2019 dan semester Genap Tahun 2019/2020. Yang artinya pada semester Genap Tahun 2018/2019 merupakan semester 2 dan semester Genap Tahun 2019/2020 merupakan semester 4 . 
Pada semester genap Genap Tahun 2018/2019 pembelajaran atau kegiatan belajar mengajar menggunakan metode Pembelajaran luring atau pembelajaran tatap muka yang dilaksanakan selama empat bulan penuh. Proses pembelajaran khususnya pada Semester Genap Tahun 2018/2019 selalu berdampingan, baik itu mata kuliah teori maupun praktek. Dengan adanya aktivitas antara peserta didik dan pendidik secara langsung dapat menunjang tercapainya tujuan pembelajaran. Tang (2013), pembelajaran tatap muka merupakan pembelajaran kelas yang mempertemukan antara pendidik dan peserta didik. Dimana dalam pembelajaran tatap muka peserta didik terlibat langsung dengan proses interaksi secara verbal, spontan terhadap lingkungan fisik. Hal ini terjadi pada Proses pembelajaran semester genap tahun 2018/2019 dimana proses pembelajaran selalu berdampingan baik itu mata kuliah teori maupun praktek. Dengan adanya aktivitas antara peserta didik dan pendidik secara langsung dapat menunjang tercapainya tujuan pembelajaran.

Selanjutnya proses pembelajaran atau kegiatan belajar mengajar di semester genap tahun 2019/2020 menggunakan dua metode pembelajaran, yaitu pembelajaran luring dan pembelajaran daring yang dilaksanakan selama dua bulan menggunakan pembelajaran luring dan pembelajaran daring dilaksanakan dalam dua bulan. Proses pelaksanaan pembelajaran pada semester ini berbeda dengan semester sebelumnya. Hal ini dikarenakan untuk menghindari penyebaran virus di lingkungan satuan pendidikan virus ini disebut dengan istilah. Covid-19. Sesuai dengan surat edaran yang dikeluarkan oleh kemendikbud dikti No. 3. Tahun 2020 (Kemendikbud, 2020).

Bilfaqih \& Qomarudin (2016) pembelajaran daring adalah pembelajaran yang diselenggarakan melalui jejaring web. Setiap mata kuliah/pelajaran menyediakan materi dalam bentuk rekaman video atau slideshow, dengan tugas-tugas mingguan yang harus dikerjakan dengan batas waktu pengerjaan yang telah ditentukan dan beragam sistem penilaian. Kuntarto (2017), pembelajaran dengan menggunakan sistem daring mampu mempertemukan antara dosen dan mahasiswa untuk melaksanakan proses interaksi dalam pembelajaran menggunakan bantuan internet.

Dalam Pembelajaran atau perkuliahan di Prodi PJKR, mahasiswa dituntut belajar pada dua domain secara bersamaan, yaitu belajar mata kuliah praktik atau belajar gerak dan belajar mata kuliah teori yaitu berhubungan dengan domain kognitif. Agar tujuan tersebut dapat dicapai maka prinsip belajar khususnya belajar gerak dan teori penting untuk diterapkan.

Rusman (2017), menyatakan bahwa terdapat tiga prinsip pada proses.pembelajaran, diantaranya yang pertama adalah proses pembelajaran adalah wahana untuk menciptakan kreasi terhadap lingkungan yang berfungsi mengubah cara berpikir (kognitif) peserta didik. Kedua, berkaitan dengan pengetahuan yang dipelajari. Ketiga, hal yang berkaitan dengan lingkungan sosial, Prinsip-prinsip belajar relatif berlaku umum, yang hubunganya dengan motivasi, keaktifan dalam belajar,keterlibatan langsung, pengulangan, tantangan, penguatan, serta kemampuan individu (Rusman, 2017).

Sardiman (2016) prestasi belajar merupakan kemampuan nyata yang merupakan hasil interaksi antara berbagai faktor yang mempengaruhi baik dari dalam maupun dari luar individu dalam belajar. Irawan et al., (2017) Prestasi belajar merupakan hasil yang diperoleh dari proses belajar yang mengakibatkan perubahan dalam diri seseorang. 
Berdasarkan hasil rekapitulasi analisis data pada variabel prestasi belajar prestasi belajar semester Genap Tahun 2018/2019 memperoleh nilai rata-rata sebesar 3,37 sedangkan pada variabel prestasi belajar semester Genap Tahun 2019/2020 memperoleh nilai rata-rata sebesar 3,40. Sehingga dapat diketahui bahwasannya hasil prestasi belajar semester Genap Tahun 2019/2020 dengan menggunakan metode pembelajaran luring dan daring cenderung lebih baik daripada hasil prestasi belajar semester Genap Tahun 2019/2020 dengan menggunakan dua metode pembelajaran yaitu, pembelajaran luring dan daring walaupun, Tidak terdapat perbedaan yang signifikan pada hasil belajar tersebut.

Mengapa proses pembelajaran luring yang terjadi semester Genap Tahun 2018/2019 dan pembelajaran luring dan daring yang terjadi semester Genap Tahun 2019/2020 tidak terdapat perbedaan yang signifikan pada prestasi belajar? Hal ini dikarenakan proses pelaksanaan pembelajaran daring dalam kegiatan belajar-mengajar juga tidak sepenuhnya efektif, hal ini didasari oleh pengalaman pribadi dari peneliti sendiri yang pernah mengikuti kegiatan perkuliahan pada tahun ajaran 2019/2020.

Dalam proses belajar mengajar pembelajaran daring berbeda dengan proses belajar mengajar pada umumnya, dimana pembelajaran daring yang menggunakan jaringan internet membuat proses pembelajaran menjadi tidak terkontrol. Seringkali peserta didik tidak mengikuti instruksi yang diberikan pendidik, seperti halnya tidak menyalakan kamera pada saat proses pembelajaran berlangsung, sehingga kemungkinan peserta didik meninggalkan kegiatan belajar mengajar semakin tinggi. Selain itu proses belajar mengajar yang kaitanya dengan pembelajaran praktek atau mata kuliah praktek juga dilakukan secara daring. hal ini juga menjadi hal baru yang dilakukan oleh peserta didik. seperti yang kita ketahui bahwa pembelajaran mata kuliah praktik yang memerlukan aktivitas fisik menjadi sulit untuk dilaksanakan sehingga proses interaksi peserta didik dan pendidik menjadi menjadi berkurang. Hal ini juga didasari oleh pengalaman pribadi peneliti yang pernah mengikuti kegiatan perkuliahan daring pada tahun ajaran 2019/2020.

Keterbatasan interaksi antara peserta didik dan pendidik ini menjadi hal yang diwaspadai oleh pendidik saat proses pembelajaran berlangsung, dikarenakan dalam kegiatan aktivitas fisik resiko cedera sangat bisa terjadi, sehingga peran pendidik untuk mengawasi proses pembelajaran menjadi sangat penting.

Sesuai dengan hukum belajar yang dikemukakan Thorinndike dalam Ali (2014), terdapat tiga prinsip belajar meliputi Law of Readiness, yaitu belajar akan berhasil apabila terdapat kesiapan untuk melakukan perbuatan tersebut. Kedua, Law of Exercise belajar akan berhasil apabila seseorang melakukan latihan-latihan dan pengulangan. Ketiga, Law of Effect belajar akan bersemangat apabila mengetahui hasil yang didapatkan sesuai. Mengacu pada prinsip belajar yang pertama yaitu Law of Readiness, belajar akan berhasil apabila individu memiliki kesiapan untuk melakukan perbuatan tersebut artinya jika hasil belajar memuaskan maka terdapat kesiapan belajar pada peserta didik atau sebaliknya jika hasil belajar tidak memuaskan maka tidak ada kesiapan belajar pada peserta didik. Sehingga keefektivitasan pembelajaran daring menjadi hal yang perlu dikaji kembali oleh pendidik.

Berdasarkan uraian diatas, dapat dikemukakan bahwa tidak ada perbedaan yang signifikan pada hasil prestasi belajar Mahasiswa Angkatan 2018 Antara Semester Genap Tahun 2018/2019 Dan 2019/2020 Prodi PJKR-FIK-UM, dikarenakan pembelajaran daring masih belum efektif untuk membantu mahasiswa dalam meningkat prestasi belajarnya. 
Hasil penelitian ini selaras dengan penelitian yang dilakukan oleh Widiyono (2020), tentang "Efektifitas. Perkuliahan Daring (Online) pada Mahasiswa PGSD di Saat Pandemi Covid 19" dan penelitian sejenis yang dilakukan oleh Ningsih (2020), tentang "Persepsi Mahasiswa Terhadap Pembelajaran Daring Pada Masa Pandemi Covid-19". Bahwasanya perkuliahan yang dilakukan secara daring belum efektif untuk membantu mahasiswa dalam belajar, Sedangkan untuk sistem perkuliahan yang efektif selama pandemi adalah daring dan luring. Selain itu mayoritas mahasiswa lebih menyukai pembelajaran secara offline atau tatap muka.

\section{Simpulan}

Berdasarkan hasil penelitian pada variabel prestasi belajar mahasiswa angkatan 2018 semester Genap Tahun 2018/2019 dan semester Genap Tahun 2019/2020. Dapat simpulkan bahwa tidak ada perbedaan yang signifikan pada hasil prestasi belajar Mahasiswa Angkatan 2018 Semester Genap Tahun 2018/2019 Dan 2019/2020 Prodi PJKR-FIK-UM.

\section{Daftar Rujukan}

Bilfaqih, Y., \& Qomarudin, M. N. (2018). Esensi Penyusunan Materi Pembelajaran Daring. Jogjakarta: Deepublish.

Febianti, Y. N., \& Joharudin, M. (2018). Faktor-Faktor Ekstern Yang Mempengaruhi Prestasi Belajar Mahasiswa. Edunomic Jurnal Pendidikan Ekonomi, 5(2), 76. https://doi.org/10.33603/ejpe.v5i2.246

H. Gani Ali. (2014). Prinsip-prinsip Pembelajaran dan Implikasinya Terhadap Pendidik dan Peserta didik. Jurnal Al-Ta'dib Tanggung, 6(1), 31-42.

Husnawati, M. M., \& Aila, R. (2018). Perbedaan prestasi belajar mahasiswa lulusan madrasah aliyah dan sekolah menengah umum pada mata pelajaran Bahasa Arab. Fitra, 3(1).

Irawan, V. T., Sutadji, E., \& Widiyanti. (2017). Blended learning based on schoology: Effort of improvement learning outcome and practicum chance in vocational high school. Cogent Education, 4(1). https://doi.org/10.1080/2331186X.2017.1282031

Kuntarto, E. (2017). Keefektifan Model Pembelajaran Daring Dalam Perkuliahan Bahasa Indonesia di Perguruan tinggi. Journal Indonesian Language Education and Literature, 3(1), 53-65.

Mudjiono, D. D. (2015). Belajar Dan Pembelajaran (Rineka Cip). Jakarta.

Ningsih, S. (2020). Persepsi Mahasiswa Terhadap Pembelajaran Daring Pada Masa Pandemi Covid-19. JINOTEP (Jurnal Inovasi Dan Teknologi Pembelajaran): Kajian Dan Riset Dalam Teknologi Pembelajaran, 7(2), 124-132. https://doi.org/10.17977/um031v7i22020p124

Rahyubi, H. (2014). Teori-teori Belajar dan Aplikasi Pembelajaran Motorik (1st ed.; Nurdin, ed.). Bandung: Nusa Media.

Rusman. (2017). Belajar dan Pembelajaran Berorientasi Standar Proses Pendidikan. Jakarta: Kencana.

Sardiman. (2016). Interaksi dan Motivasi Belajar-Mengajar. Jakarta: PT Raja Grafindo Persada.

Slameto. (2015). Belajar dan Faktor Yang Mempengaruhinya. Jakarta: Rineka Cipta. Jakarta: Rineka cipta.

Soepardjo, S. (2013). Kontribusi status sosial ekonomi keluarga dan sikap kebangsaan terhadap prestasi belajar Sejarah. Jurnal Penelitian dan Evaluasi Pendidikan, 17(1), 106-126.

Sofyana, L., \& Rozaq, A. (2019). Pembelajaran Daring Kombinasi Berbasis Whatsapp Pada Kelas Karyawan Prodi Teknik Informatika Universitas PGRI Madiun. Jurnal Nasional Pendidikan Teknik Informatika (JANAPATI), 8(1), 81. https://doi.org/10.23887/janapati.v8i1.17204

Sunendar, Dadang, dkk. (2005). (Tim Penyusun KBBI Edisi Kelima). (2020). Kamus Besar Bahasa Indonesia. Jakarta: Badan Pengembangan dan Pembinaan Bahasa, Kementerian Pendidikan dan Kebudayaan Republik Indonesia Suparlan. (2005). Menjadi Guru Efektif.

Tang, C. M. (2013). Readiness for Blended Learning: Understanding Attitude of University Students. International Journal of Cyber Society and Education, 6(2), 79-100. https://doi.org/10.7903/ijcse.1086

Thobroni, M. (2015). Belajar dan pembelajaran teori dan praktik. Yogyakarta: Ar-Ruzz Media.

Wiarto, G. (2015). Inovasi Pembelajaran Dalam Pendidikan Jasmani. Jogjakarta: Laksitas. 
Sport Science and Health, 3(6), 2021, 350-358

Widiyono, A. (2020). Efektifitas Perkuliahan Daring (Online) pada Mahasiswa PGSD di Saat Pandemi Covid 19. Jurnal Pendidikan, 8(2), 169-177. https://doi.org/10.36232/pendidikan.v8i2.458 